\title{
Asumsi Dasar pada Ilmu Pengetahuan yang menjadi Basis Penelitian Pendidikan Islam
}

\author{
Eko Budi Prasetyo ${ }^{1}$, Nanat Fatah Natsir ${ }^{2}$, Erni Haryanti ${ }^{3}$ \\ 1,2,3Universitas Islam Negeri Sunan Gunung Djati Bandung, Indonesia \\ E-mail: muhammadnayif1@gmail.com,nanatfatahnatsir@uinsgd.ac.id,erni_hk@uinsgd.ac.id
}

\begin{abstract}
Article Info
Article History

Received: 2021-12-27

Revised: 2022-01-22
\end{abstract}

Published: 2022-02-01

Keywords:

Assumption;

Science;

Study;

Islamic Education.

\begin{abstract}
This study explains the basic assumptions in science that are the basis of Islamic education research. The method used in this study uses a library research method or approach, that library research can be interpreted as a series of activities related to the methods of collecting library data, reading and taking notes and processing research materials. The results of this study indicate that the assumptions in the study of philosophy of science belong to the ontology group, namely the chapter that discusses the nature of existence. To process knowledge into science, it is necessary to conduct research and experiments using the scientific method. Assumptions act as conjectures or assumptions about empirical objects to obtain knowledge, which is needed as a direction or basis for research activities before something being researched is proven true. Research is a tool to develop knowledge, the results of which will find new theories and induction-consultation. Likewise, in developing Islamic education, research needs to be carried out. The basic assumptions of science as the basis of Islamic research are derived from empiricism, rationalism, intuition, and revelation. Islamic education research includes research on knowledge of Islamic educational philosophy, mystical knowledge of Islamic Education and Islamic Educational Science. From the research of Islamic Education Sciences (empirical science) theories will emerge which are then adapted to Islamic teachings. These theories will later be called the theory of Islamic Education.
\end{abstract}

\begin{tabular}{l}
\hline Artikel Info \\
\hline Sejarah Artikel \\
Diterima: 2021-12-27 \\
Direvisi: 2022-01-22 \\
Dipublikasi: 2022-02-01
\end{tabular}

Kata kunci: Asumsi; Ilmu Pengetahuan; Penelitian;

Pendidikan Islam.

\begin{abstract}
Abstrak
Penelitian ini menjelaskan tentang asumsi dasar pada ilmu pengetahuan yang menjadi basis penelitian pendidikan islam. Metode yang digunakan dalam kajian ini menggunakan metode atau pendekatan kepustakaan (library research), bahwa studi pustaka atau kepustakaan dapat diartikan sebagai serangkaian kegiatan yang berkenaan dengan metode pengumpulan data pustaka, membaca dan mencatat serta mengolah bahan penelitian. Hasil penelitian ini menunjukkan bahwa asumsi dalam kajian filsafat ilmu tergolong ke dalam kelompok ontologi, yaitu bab yang membahas tentang hakikat yang ada. Untuk mengolah pengetahuan menjadi ilmu pengetahuan (sains) perlu dilakukan penelitian dan eksperimen menggunakan metode ilmiah. Asumsi berperan sebagai dugaan atau andaian terhadap objek empiris untuk memperoleh pengetahuan, yang diperlukan sebagai arah atau landasan bagi kegiatan penelitian sebelum sesuatu yang diteliti tersebut terbukti kebenarannya. Penelitian merupakan alat untuk mengembangkan ilmu pengetahuan yang hasilnya akan menemukan teori-teori baru maupun induksi-konsultasi. Begitupun dalam mengembangkan ilmu pendidikan Islam perlu diadakan penelitian. Asumsi-asumsi dasar ilmu pengetahuan sebagai basis penelitian Islam bersumberkan dari empirisme, rasionalisme, intuisi, maupun wahyu. Penelitian pendidikan Islam mencakup penelitian terhadap pengetahuan filsafat pendidikan Islam, pengetahuan mistik Pendidikan Islam dan Ilmu Pendidikan Islam. Dari penelitian Ilmu Pendidikan Islam (sains yang empiris) itu akan mucul teori yang selanjutnya disesuaikan dengan ajaran Islam. Teori-teori itulah yang kelak disebut teori Ilmu Pendidikan Islam.
\end{abstract}

\section{PENDAHULUAN}

Perkembangan ilmu pengetahuan akan membawa dampak positif bagi kehidupan umat manusia, diantaranya mempermudah aktifitas manusia, memberikan berbagai kemudahan, mempercepat dan mempermudah proses infor-masi dan distribusi dalam kegiatan ekonomi, menambah efektifitas dan efisiensi dalam interaksi sosial masyarakat (Irwansyah, 2021). Perkembangan ilmu dan pengetahuian juga dapat meningkatan di bidang produksi, menam-bah pengetahuan dan wawasan, perusahaan atau industri dapat menjual produknya lebih luas lagi, meningkatkan kualitas Pendidikan dan masih banyak lagi. 
Manusia adalah makhluk berfikir yang selalu ingin tahu tentang sesuatu, rasa ingin tahu mendorong manusia mengemukakan pertanyaan (Arifudin, 2020), bertanya tentang dirinya, lingkungan disekelilingnya, ataupun berbagai peristiwa yang terjadi disekitarnya, dengan bertanya itu manusia mengumpulkan segala sesuatu yang diketahuinya. Begitulah cara manusia mengumpulkan pengetahuan, dengan demikian dapat dikatakan, bahwa pengetahuan adalah produk dari tahu, yakni mengerti sesudah melihat, menyaksikan dan mengalami (Na'im, 2021). Manusia memperoleh pengetahuan melalui berbagai cara. Bila hanya sekedar ingin tahu tentang sesuatu cukup dengan menggunakan pertanyaan sederhana, namun disamping itu, adakalanya pengetahuan itu diperoleh melalui pengalaman yang berulang-ulang terhadap suatu peristiwa atau kejadian, ada juga pengetahuan diperoleh dari usaha dalam mengatasi masalah yang berhubungan dengan kebutuhan hidup (Bairizki, 2021). Adakalanya pula pengetahuan diperoleh dengan percobaan sederhana atau dikenal dengan trial and error, pengetahuan dari hasil coba-coba (Jalaluddin, 2015). Pengetahuan seperti ini disebut pengetahuan alamiah, pengetahuan biasa atau pengetahuan. Jadi awalnya masih sangat sederhana, hanya sekedar ingin tahu tentang sesuatu melalui proses berfikir alamiah, secara sederhana dan apa adanya. Berfikir alamiah itu sendiri merupakan pola penalaran yang berdasarkan kebiasaan seharihari dari pengaruh alam sekelilingnya, proses memperoleh pengetahuan secara sederhana dimulai dari pengamatan sekitar kemudian dicari hubungan sebab akibat, lalu diambil kesimpulan (Nadeak, 2020). Tanpa dilakukan analisis dan pengujian lebih lanjut berdasarkan proses keilmuan, oleh karena itu kesimpulan yang diambil mungkin saja bersifat kebetulan atau kebenaran sesaat.

Dalam konteks pengetahuan, berdasar pada kondisi alamiahnya bahwa semua manusia mencintai apa yang disebut dengan pengetahuan dan begitu pula sebaliknya, tidak menyukai apa yang disebut sebagai ketidaktahuan (Fatira, 2021). Manusia menyukai pengetahuan disebabkan karena keberadaan akal budi yang ada dalam dirinya, rasa kagum (thauma) yang dimiliki, serta berbagai persoalan yang harus mereka hadapi, yang menuntut adanya pengetahuan untuk menyelesaikannya (Hamdani, 2011), adapun yang dimaksud dengan sumber pengetahuan adalah faktor yang melatarbelakang lahirnya ilmu pengetahuan (Mayasari, 2021), dari mana atau dengan cara bagaimana manusia memperoleh ilmu pengetahuan itu, Maka setidaknya ada empat sumber pengetahuan manusia yaitu:

1. Empirisme (Pengalaman Manusia)

Dengan ini muncul aliran Empirisme yang dipelopori oleh Jhon Locke, manusia dilahirkan sebagai kertas putih pengalamanlah yang akan memberikan lukisan kepadanya, dunia empiris merupakan sumber pengetahuan, utama dalam dunia pendidikan, terkenal dengan teori tabula rasa (teori kertas putih). Aliran ini berpendapat bahwa pengetahuan dapat dapat diperoleh melalui pengamatan, dengan jalan observasi, atau jalan penginderaan (Burhanudin, 1997).

2. Rasionalisme, (Pikiran Manusia)

Hal ini melahirkan paham Rasionalisme yang berpendapat bahwa sumber satu-satunya dari pengetahuan manusia adalah rasionya (akal budinya) pelopornya ialah Rene Descartes, aliran ini sangat mendewakan akal budi manusia yang melahirkan faham intelektualisme dalam dunia pendidikan.

3. Intuisionisme (intuisi)

Secara etimologis intuisi berarti langsung melihat, pengertian secara umum merupakan suatu metode yang tidak berdasarkan penalaran maupun pengalaman dan pengamataan indra (Jalaluddin, 2015).

4. Wahyu Allah

Wahyu Allah adalah pengetahuan yang disampaikan oleh Allah kepada manusia lewat para nabi yang diutus-Nya sejak nabi pertama sampai terakhir. Wahyu adalah isyarat yang cepat atau bisikan halus atau firman tuhan yang disampaikan kepada para anbiya, para filusuf muslim juga mengakui wahyu sebagai sumber ilmu pengetahuan.

Pada konteks asumsi dalam kajian filsafat ilmu tergolong ke dalam kelompok ontologi, yaitu bab yang membahas tentang hakikat yang ada, yang merupakan ultimate reality baik yang berbentuk konkret atau abstrak. Asumsi berperan sebagai dugaan atau andaian terhadap objek empiris untuk memperoleh pengetahuan, kemudian diperlukan sebagai arah atau landasan bagi kegiatan penelitian sebelum sesuatu yang diteliti tersebut terbukti kebenarannya, metode ilmiah (seperti empiris-eksperimental) adalah hasil penemuan yang telah diupayakan manusia dalam waktu yang cukup lama (Darmawan, 2021). Dasar-dasarnya sudah ada pada masa Yunani dan dikembangkan oleh sarjana-sarjana muslim pada masa kejayaan peradaban Islam dan kemudian dirumuskan langkah-langkahnya 
lebih terperinci pada masa modern. Metode ilmiah didasarkan pada sejumlah asumsi- asumsi yang biasanya diterima begitu saja (Akhyar, 2015).

Asumsi sangat erat kaitannya dengan metodologi penelitian ilmu pengetahuan, karena pengetahuan diperoleh melalui pendekatan ilmiah, yakni melalui "penyelidikan yang sistematik, terkontrol dan bersifat empiris atas suatu relasi fenomena alam. Metode ilmiah merupakan prosedur atau langkah-langkah sistematis dalam mendapatkan pengetahuan ilmiah atau ilmu (Arifudin, 2021). Ilmu merupakan pengetahuan yang didapatkan metode ilmiah, metode adalah suatu prosedur atau cara untuk mengetahui sesuatu dengan langkah-langkah sistematis (Endang, 2011), dalam konteks penelitian, bahwa perkembangan dan pengembangan ilmu pengetahuan mensyaratkan dan memutlakkan adanya kegiatan penelitian. Tanpa penelitian itu ilmu pengetahuan tidak dapat hidup (Ulfah, 2022). Memang penelitian merupakan suatu tugas agar bangunan ilmu pengetahuan tidak kabur, tanpa stuktur jelas, tanpa sistematik atau dengan metode serta tujuan yang kacau, pada pokoknya kegiatan penelitian merupakan upaya merumuskan permasalahan, mengajukan pertanyaanpertanyaan, dan mencoba menjawab pertanyaanpertanyaan tersebut, dengan jalan menemukan fakta-fakta dan memberikan penafsiran yang benar (Hasbi, 2021). Tetapi lebih dinamis lagi penelitian juga berfungi dan bertujuan inventif, yakni terus menerus memperbaharui lagi kesimpulan teori yang telah diterima berdasarkan fakta-fakta yang telah ditemukan (Anton, 1992).

Pendidikan Islam yang bertujuan untuk membimbing pertumbuhan rohani dan jasmani pemeluknya menurut ajaran perlu dikembangkan dengan penelitian, pendidikan Islam merupakan hal yang wajib untuk dilaksanakan untuk mengembangkan konsep-konsep pendidikan Islam dan upaya menjawab permasalahan yang terjadi dalam dunia pendidikan Islam (Supriani, 2022). Maka suatu falsafah pendidikan yang berdasar Islam tidak lain adalah pandangan dasar tentang pendidikan yang bersumber pada ajaran Islam, yang orientasi pemikirannya berdasarkan ajaran tersebut.

\section{METODE PENELITIAN}

Sesuai dengan karakteristik masalah yang diangkat dalam penelitan ini maka menggunakan Metode Riset kualitatif yaitu menekankan analisanya pada data deskriptif berupa kata-kata tertulis yang diamati, pendekatan kualitatif penulis gunakan untuk menganalisis kajian jaring laba-laba, interaksi-interkoneksi Universitas Islam Negeri Sunan Kalidjaga Yogyakarta, maka dengan sendirinya penganalisaan data ini lebih difokuskan pada Penelitian Kepustakaan (Library Research), yakni dengan membaca, menelaah dan mengkaji buku-buku dan sumber tulisan yang erat kaitannya dengan masalah yang dibahas. Metode yang digunakan dalam kajian ini menggunakan metode atau pendekatan kepustakaan (library research), menurut Zed dalam (Rahayu, 2020) bahwa studi pustaka atau kepustakaan dapat diartikan sebagai serangkaian kegiatan yang berkenaan dengan metode pengumpulan data pustaka, membaca dan mencatat serta mengolah bahan penelitian.

Jenis penelitian ini adalah penelitian kualitatif, menurut Ibnu dalam (Nasser, 2021) penelitian kualitatif adalah suatu penelitian yang datanya dinyatakan dalam bentuk verbal dan dianalisis tanpa menggunakan teknik statistik, berdasarkan beberapa definisi penelitian kualitatif di atas dapat disimpulkan bahwa penelitian kualitatif adalah suatu penelitian yang datanya dinyatakan dalam bentuk verbal, tidak menggunakan angka dan analisisnya tanpa menggunakan teknik statistik.

1. Objek Penelitian

Dalam penelitian ini objek penelitian terdiri dari 2 (dua), yaitu objek formal dan objek material (Arifudin, 2020), objek formal dalam penelitian ini berupa data yaitu data yang berhubungan dengan tinjauan kritis jaring laba-laba, interaksi-interkoneksi Universitas Islam Negeri Sunan Kalidjaga Yogyakarta. Sedangkan objek materialnya berupa sumber data, dalam hal ini adalah tinjauan kritis terhadap asumsi dasar pada ilmu pengetahuan yang menjadi basis penelitian pendidikan islam.

2. Waktu Penelitian

Penelitian ini dilaksanakan pada bulan Oktober sampai dengan Desember tahun 2021.

3. Teknik Pengumpulan Data

Pengumpulan data yang dilakukan dengan menggunakan teknik dokumentasi yaitu mengadakan survey bahan kepustakaan untuk mengumpulkan bahan-bahan dan studi literatur yakni mempelajari bahan-bahan yang berkaitan dengan objek penelitian. Teknik pengumpulan data menurut (Bahri, 2021) mengemukakan bahwa merupakan langkah yang paling strategis dalam penelitian karena 
tujuan untama dari penelitian adalah mendapatkan data, terdapat beberapa cara atau teknik dalam mengumpulkan data, diantaranya adalah observasi dan dokumentasi. Sumber data yang digunakan dalam penelitian ini mencakup data primer dan sekunder. Menurut (Hanafiah, 2021) bahwa data primer adalah data yang dikumpulkan langsung dari individu-individu yang diselidiki atau data tangan pertama, sedangkan data sekunder adalah data yang ada dalam pustaka-pustaka. Data primer dalam penelitian ini adalah bukubuku terkait tinjauan kritis kajian terhadap asumsi dasar pada ilmu pengetahuan yang menjadi basis penelitian pendidikan islam, dan data sekunder didapatkan dari jurnaljurnal baik nasional maupun internasional.

4. Alat Pengumpulan Data

Dalam penelitian ini penulis akan menggunakan metode dokumentasi sebagai alat untuk pengumpul data karena penelitian ini adalah penelitian kepustakaan, dengan kata lain menurut (Juhji, 2020) bahwa teknik ini digunakan untuk menghimpun data-data dari sumber primer maupun sekunder.

5. Teknik Analisis Data

Analisis data tidak saja dilakukan setelah data terkumpul, tetapi sejak tahap pengumpulan data proses analisis telah dilakukan. Penulis menggunakan strategi analisis "kualitatif", strategi ini dimaksudkan bahwa analisis bertolak dari data-data dan bermuara pada kesimpulan-kesimpulan umum, berdasarkan pada strategi analisis data ini, dalam rangka membentuk kesimpulan-kesimpulan umum analisis dapat dilakukan menggunakan kerangka pikir "induktif". Menurut (Sugiyono, 2015) bahwa metode pembahasan menggunakan metode deskriptif-analisis, yaitu menjelaskan serta mengelaborasi ide-ide utama yang berkenaan dengan topik yang dibahas, kemudian menyajikannya secara kritis melalui sumber-sumber pustaka primer maupun skunder yang berkaitan dengan tema.

6. Prosedur Penelitian

Data pada penelitian ini dicatat, dipilih dan kemudian diklasifikasikan sesuai dengan kategori yang ada, pendekatan yang digunakan adalah pendekatan deskriptif analitis. Menurut (Arifudin, 2019) bahwa deskriptif analitis (descriptive of analyze research), yaitu pencarian berupa fakta, hasil dari ide pemikiran seseorang melalui cara mencari, menganalisis, membuat interpretasi serta melakukan generalisasi terhadap hasil penelitian yang dilakukan. Prosedur penelitian ini adalah untuk menghasilkan data deskriptif yang berupa data tertulis setelah melakukan anaisis pemikiran (content analyze) dari suatu teks. Setelah penulis mengumpulkan bahanbahan yang berhubungan dengan masalah yang akan di bahas dalam penelitian ini, kemudian penulis menganalisis dan menarasikan untuk diambil kesimpulan.

\section{HASIL DAN PEMBAHASAN}

Dalam pembahasan asumsi dasar pada ilmu pengetahuan yang menjadi basis penelitian pendidikan islam ini akan dibahas tentang Asumsi, dan Penelitian Pendidikan Islam.

1. Asumsi

Asumsi atau anggapan dasar ialah anggapan yang menjadi titik tolak penelitian, asumsi secara implisit terkandung dalam paradigma, perspektif dan kerangka teori yang digunakan dalam penelitian, asumsi umumnya diterima begitu saja sebagai suatu yang benar dengan sendirinya, asumsi biasa berasal dari postulat, yaitu kebenaran (dalildalil) apriori yang tidak dapat dibuktikan kebenarannya. Michel Polanyi menyebut asumsi-asumsi itu sebagai dimensi yang tidak terungkap atau tersembunyi dalam ilmu pengetahuan. Misalnya dalam empirisme terkandung asumsi bahwa alam ini ada, fenomena alam seragam dan sama dimana saja, alam dapat diketahui melalui pengamatan dan rasio atau metode empirisekperimental, fenomena alam ditentukan oleh hukum-hukum alam (deterministik) dan seterusnya (Akhyar, 2015). Setiap ilmu memerlukan asumsi. Asumsi diperlukan untuk mengatasi penelaahan suatu permasalahan menjadi lebar, asumsi ini perlu sebab pernyataan asumtif inilah yang memberi arah dan landasan bagi kegiatan penelaahan kita. Sebuah pengetahuan baru dianggap benar selama kita bisa menerima asumsi yang dikemukakannya, semua teori mempunyai asumsi-asumsi ini, baik yang dinyatakan secara tersurat maupun yang tercakup secara tersirat.

Ilmu menganggap bahwa obyek obyek empiris yang menjadi bidang penelaahannya mempunyai sifat keragaman, memperlihatkan sifat berulang dan semuanya saling menjalin secara teratur, bahwa hujan yang turun diawali dengan awan yang tebal dan langit yang mendung, hal ini bukan merupakan suatu hal yang kebetulan tetapi memang 
polanya sudah demikian. Kejadian ini akan terulang dengan pola yang sama, alam merupakan suatu sistem yang teratur yang tunduk pada hukum-hukum tertentu, dalam mengembangkan asumsi maka harus diperhatikan beberapa hal yaitu asumsi harus relevan dengan bidang ilmu dan tujuan pengkajian disiplin keilmuan serta asumsi ini harus disimpulkan dari "keadaan sebagaimana adanya" bukan "bagaimana keadaan seharusnya" asumsi yang pertama adalah asumsi yang mendasari telaah ilmiah sedangkan asumsi kedua adalah asumsi yang mendasar telah moral. Sekiranya dalam kegiatan ekonomis maka manusia yang berperan adalah manusia "yang mencari keuntungan yang sebesar-besarnya dengan korbanan sekecil- kecilnya" maka itu sajalah yang kita jadikan pegangan tidak usah ditambah sebaiknya begini, atau seharusnya begitu, berdasarkan paparan diatas dapat disimpulkan bahwa asumsi ilmu sangat diperlukan karena setiap ilmu memerlukan asumsi, asumsi diperlukan untuk mengatasi penelaahan suatu permasalahan menjadi lebar dan Asumsi inilah yang memberi arah dan landasan bagi kegiatan penelaahan kita.

\section{Penelitian Pendidikan Islam}

Pendidikan Islam merupakan salah satu bidang studi Islam yang mendapat banyak perhatian dari para ilmuwan, hal ini dikarenakan peranannya yang sangat strategis dalam rangka meningkatan sumber daya manusia. Ilmu pengetahuan berkembang sesuai dengan perkembangan kebutuhan manusia, sedangkan kebutuhan manusia adalah sesuatu yang berkembang di dalam dan bersama dengan perkembangan kebudayaan. maka manusia selalu berupaya berdasarkan disiplin metodologi ilmiah, dengan tujuan menemukan prinsip-prinsip baru untuk mengantisipasi perubahan dan perkembangan kebutuhannya, itulah yang disebut penelitian (Anton, 1992).

Ilmu Pendidikan Islam, cakupannya ialah masalah-masalah yang berada dalam tataran ilmu (sains), yaitu objek-objek yang logis dan empiris tentang pendidikan, maka pengetahuan (ilmu) pendidikan Islam terdiri dari pengetahuan filsafat pendidikan, tasawuf pendidikan dan ilmu pendidikan (Tafsir, 1995), dengan demikian maka penelitian pendidikan Islam mencakup penelitian terhadap pengetahuan filsafat pendidikan
Islam, pengetahuan tasawuf Pendidikan Islam, dan Ilmu Pendidikan Islam. Penelitian dalam arti kajian logika dan tasawuf telah banyak dilakukan para ulama Islam, sementara itu kajiwean atau tepatnya penelitian terhadap ilmu Pendidikan yang bersifat empris dinilai masih belum banyak dilakukan pakar Islam, sedangkan kajian dengan yang terakhir inilah menjadi modal bagi pegembangan ilmu pendidikan Islam.

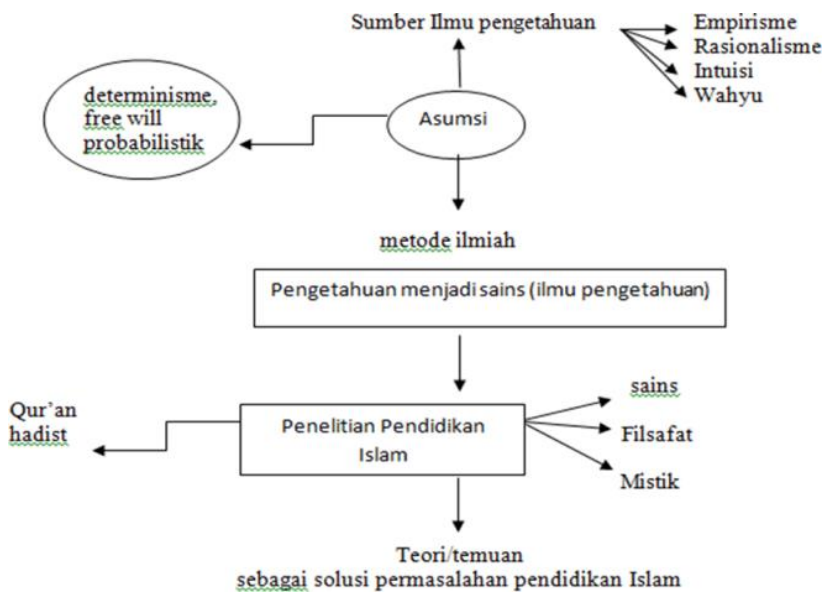

Gambar 1. Skema Asumsi Dasar Ilmu Pengetahuan Sebagai Basis Penelitian Pendidikan Islam

Dari penelitian Ilmu Pendidikan Islam (sains yang empiris) itu akan mucul teori yang selanjutnya disesuaikan dengan ajaran Islam. Teori-teori itulah yang kelak disebut teori Ilmu Pendidikan Islam, dengan demikian pengembangan Ilmu Pendidikan Islam tidaklah mencakup pekerjaan mengembangkan filsafat pendidikan Islam dan tidak pula mengembangkan manual-manual pendidikan Islam. Teori-teori yang perlu dikembangkan dalam Ilmu pendidikan Islam sangat luas mulai dari teori tentang pendidikan Islam pada masa pra natal, jika hendak mengembangkan ilmu pendidikan Islami maka kita harus mengembangkan teori-teori ilmu pendidikan islami tersebut, mengembangkan ilmu berarti mengembangkan teori, dalam pengembangan teori tersebut itu, apakah merevisi, mengganti ataupun membuat teori diperlukan metode yang menjelaskan cara kerja yang terpertanggungjawabkan, jika kita merevisi teori yang atau hendak mengganti teori itu berarti teori lama sudah ada. Teori lama yang ada dan banyak ialah teori pendidikan dari barat, apa salahnya kita mulai dengan memeriksa teori pendidikan barat tersebut, lantas kita konsultasikan ke Islam (al-qur'an, 
hadist) boleh jadi teori itu kita terima, kita revisi, atau kita tolak, inilah persoalan islamisasi ilmu pendidikan dalam rangka mengembangkan pendidikan Islami. Jika cara ini ditempuh maka kita dikatakan menggunakan metode induksi- konsultasi, ada dua arus yang muncul tentang cara pengembangan Ilmu Pendidikan Islami yaitu cara deduksi yaitu kita mulai dari teks wahyu atau sabda rasul lantas ditafsirkan, dari sini muncul teori pendidikan pada tingkat filsafat teori itu dieksperimenkan, dari sini akan muncul teori ilmu pendidikan pada tingkat ilmu (sains). Selanjutnya diuraikan lebih operasional sehingga langsung dapat dijadikan petunjuk teknis (manual).

\section{SIMPULAN DAN SARAN}

\section{A. Simpulan}

Berdasarkan pemaparan pada penelitian asumsi dasar pada ilmu pengetahuan yang menjadi basis penelitian pendidikan islam ini dapat disimpulkan bahwa empat sumber ilmu pengetahuan yaitu empirisme, rasionalisme, intuisi serta akal merupakan dasar pijakan dalam membuat asumsi. Asumsi (atau anggapan dasar) ialah anggapan yang menjadi titik tolak penelitian, asumsi secara implisit terkandung dalam paradigma, perspektif dan kerangka teori yang digunakan dalam penelitian. Ilmu mempunyai tiga asumsi mengenai hakikat keilmuan yaitu determinisme, free will dan probabilistik yang dapat disimpulkan bahwa asumsi ilmu sangat diperlukan karena setiap ilmu memerlukan asumsi. Asumsi diperlukan untuk mengatasi penelaahan suatu permasalahan menjadi lebar dan Asumsi inilah yang memberi arah dan landasan bagi kegiatan penelaahan/penelitian. Selanjutnya bahwa penelitian merupakan upaya untuk mengembangkan ilmu, mengembangkan ilmu pendidikan Islami kita harus mengembangkan teori-teori ilmu pendidikan islami tersebut. Mengembangkan ilmu berarti mengembangkan teori, dengan dua cara pertama deduktif dan kedua induksikonsultasi. Penelitian pendidikan Islam, mencakup penelitian terhadap pengetahuan filsafat pendidikan Islam, pengetahuan mistik Pendidikan Islam dan Ilmu Pendidikan Islam. Penelitian dalam arti kajian logika dan mistik telah banyak dilakukan para ulama Islam. Sementara itu kajian atau tepatnya penelitian terhadap ilmu Pendidikan yang bersifat empris dinilai masih belum banyak dilakukan pakar Islam.

\section{B. Saran}

Pembahasan terkait penelitian kajian terhadap asumsi dasar pada ilmu pengetahuan yang menjadi basis penelitian pendidikan islam dalam penelitian ini masih sangat terbatas dan membutuhkan banyak masukan. Saran untuk penulis selanjutnya adalah mengkaji lebih dalam dan secara komprehensif terkait kajian terhadap asumsi dasar pada ilmu pengetahuan yang menjadi basis penelitian pendidikan islam.

\section{DAFTAR RUJUKAN}

Akhyar. (2015). Filsafat Ilmu Klasik Hingga Kontemporer. Jakarta: Rajawali Press.

Anton. (1992). Metodologi Penelitian Filsafat. Yogyakarta: Kanisius.

Arifudin, O. (2018). Pengaruh Pelatihan Dan Motivasi Terhadap Produktivitas Kerja Tenaga Kependidikan STIT Rakeyan Santang Karawang. MEA (Manajemen, Ekonomi, \& Akuntansi), 2(3), 209-218.

Arifudin, 0. (2020). Psikologi Pendidikan (Tinjauan Teori Dan Praktis). Bandung: Widina Bhakti Persada.

Arifudin, 0. (2021). Implementasi Balanced Scorecard dalam Mewujudkan Pendidikan Tinggi World Class. Edumaspul: Jurnal Pendidikan, 5(2), 767-775.

Bahri, A. S. (2021). Pengantar Penelitian Pendidikan (Sebuah Tinjauan Teori dan Praktis). Bandung: Widina Bhakti Persada.

Bairizki, A. (2021). Manajemen Perubahan. Bandung : Widina Bhakti Persada.

Burhanudin. (1997). Logika Materiil, Filsafat Ilmu Pengetahuan. Jakarta: Rineka Cipta.

Darmawan, I. P. A. (2021). Total Quality Management Dalam Dunia Pendidikan" Model, Teknik Dan Impementasi". Bandung: Widina Bhakti Persada Bandung.

Dewantara. (1962). Bagian Pertama Pendidikan. Yogyakarta: Malis Luhur Taman Siswa. 
Endang. (2011). Filsafat Ilmu dan Metodologi Penelitian. Bandung: Reflika Aditama.

Fatira, M. (2021). Pembelajaran Digital. Bandung: Widina Bhakti Persada.

Hamdani. (2011). Filsafat Sains. Bandung: Pustaka Setia.

Hanafiah, H. (2021). Pelatihan Software Mendeley Dalam Peningkatan Kualitas Artikel Ilmiah Bagi Mahasiswa. Jurnal Karya Abdi Masyarakat, 5(2), 213-220.

Hasbi, I. (2021). Administrasi Pendidikan (Tinjauan Teori Dan Praktik). Bandung: Widina Bhakti Persada.

Irwansyah, R. (2021). Perkembangan Peserta Didik. Bandung: Widina Bhakti Persada.

Jalaluddin. (2015). Filsafat Pendidikan. Jakarta: Raja Grafindo Persada.

Juhji. (2020). Manajemen Humas Sekolah. Bandung: Widina Bhakti Persada.

Jujun. (2007). Filsafat Ilmu sebuah Pengantar Populer. Jakarta: Pancaraninta.

Mayasari, A. (2021). Implementasi Sistem Informasi Manajemen Akademik Berbasis Teknologi Informasi dalam Meningkatkan Mutu Pelayanan Pembelajaran di SMK. JIIPJurnal Ilmiah Ilmu Pendidikan, 4(5), 340345. https://doi.org/10.54371/jiip.v4i5.277

Nadeak, B. (2020). Manajemen Humas Pada Lembaga Pendidikan. Bandung: Widina Bhakti Persada.

Na'im, Z. (2021). Manajemen Pendidikan Islam. Bandung: Widina Bhakti Persada.
Nasser, A. A. (2021). Sistem Penerimaan Siswa Baru Berbasis Web Dalam Meningkatkan Mutu Siswa Di Era Pandemi. Biormatika: Jurnal Ilmiah Fakultas Keguruan Dan Ilmu Pendidikan, 7(1), 100-109.

Rahayu, Y. N. (2020). Program Linier (Teori Dan Aplikasi). Bandung : Widina Bhakti Persada.

Sofyan, Y. (2020). Peranan Konseling Dosen Wali Dalam Meningkatkan Motivasi Belajar Mahasiswa Di Perguruan Tinggi Swasta Wilayah LLDIKTI IV. Jurnal Bimbingan Dan Konseling Islam, 10(2), 237-242.

Supriani, Y. (2022). Peran Manajemen Kepemimpinan dalam Pengelolaan Lembaga Pendidikan Islam. JIIP-Jurnal Ilmiah Ilmu Pendidikan, 5(1), 332-338.

Tafsir. (1995). Epistemologi untuk Ilmu Pendidikan Islam. Bandung: Remaja Rosda Karya.

Tafsir. (2012). Ilmu Pendidikan Islam. Bandung: Remaja Rosdakarya.

Tafsir. (2012). Ilmu Pendidikan Islam. Bandung: Remaja Rosdakarya.

Tanjung, R. (2022). Manajemen Penyelenggaraan Pendidikan Inklusi pada Lembaga Pendidikan Islam. JIIP-Jurnal Ilmiah Ilmu Pendidikan, 5(1), 339-348.

Ulfah, U. (2022). Kepemimpinan Pendidikan di Era Disrupsi. JIIP-Jurnal Ilmiah Ilmu Pendidikan, 5(1), 153-161.

Zuharini. (1992). Sejarah Pendidikan Islam. Jakarta: Bumi Aksara. 